\title{
Muscle strength, lower extremity functional performance and body composition in elderly women with mild cognitive impairment
}

\author{
Força muscular, desempenho funcional de membros inferiores $e$ \\ composição corporal de idosas com comprometimento cognitivo leve
}

\author{
Érica Carvalho Caldas, Lays Aragão Rezende, Karoline da Silva Oliveira, Hudson Azevedo Pinheiro, \\ Gislane Ferreira de Melo, Karla Helena Coelho Vilaça*
}

Universidade Católica de Brasília (UCB), Brasília, DF, Brazil

\begin{abstract}
Introduction: Mild cognitive impairment (MCI) is characterized by subjective memory complaints and is considered an intermediate stage between normal and pathological cognitive function. The decline in cognitive function may be associated with low functional performance and alterations in body composition in older adults. Objective: To assess muscle strength, lower extremity functional performance and body composition in elderly women with MCI. Methods: Forty-three elderly women (aged 60-80 years) participated in the study. Participants were divided into two groups: elderly women with MCI $(\mathrm{n}=19)$ and elderly women without MCI $(n=24)$. To diagnose MCI, we used the instruments proposed by Petersen et al. According to it, the subjects had to have memory complaints that had no effects on basic or instrumental activities of daily living. Muscle strength was assessed via palmar grip strength (PGS) using a dynamometer (Jamar®) and knee extension strength (KES) was assessed using the one-repetition maximum test (1-RM). Lower extremity (LE) functional performance was assessed using the Short Physical Performance Battery (SPPB) and body composition was measured using biometrical impedance analysis (Biodynamics Model 310). Results: There was a significant difference in muscle strength between groups. The group with MCI had lower PGS
\end{abstract}

\footnotetext{
ECC: MS, e-mail: caldaserica@gmail.com LAR: BS, e-mail: lays.aragao@hotmail.com KSO: BS, e-mail: karoline.fisiot@gmail.com HAP: Doctoral student, e-mail: hudsonap@gmail.com GFM: PhD, e-mail: gmelo@ucb.br KHCV: PhD, e-mail: kavilaca@yahoo.com.br
} 
$(p=0.002)$ and KES $(p=0.002)$, when compared to their counterparts. No significant difference between groups was found for the other variables, like SPPB and body composition. We found a positive, significant correlation between SPPB and KES ( $r=0.55 ; \mathrm{p}=0.0001)$, SPPB and PGS ( $r=0.37 ; \mathrm{p}=0.0155)$, KES and PGS $(r=0.59 ; p<0.0001)$, and between lean mass and PGS ( $r=0.36 ; p=0.0184)$. Conclusion: Elderly women with MCI show reduced LE muscle strength and PGS, but no differences between groups were found for LE functional performance and body composition.

Keywords: Muscle Strength. Body Composition. Mild Cognitive Impairment. Elderly.

\section{Resumo}

Introdução: O Comprometimento Cognitivo Leve (CCL) é caracterizado pela presença de queixas subjetivas de memória, sendo considerado um estágio entre a função cognitiva normal e a patológica. O declínio das funções cognitivas pode estar relacionado ao baixo desempenho funcional e a alteração da composição corporal em idosos. Objetivo: Avaliar a força muscular, o desempenho funcional de membros inferiores e a composição corporal de idosas com CCL. Métodos: participaram do estudo 43 idosas que foram divididas em 2 grupos, sendo 19 idosas com CCL e 24 idosas sem CCL, a idade variou de 60 a 80 anos. Para diagnóstico do CCL utilizou-se os instrumentos propostos por Petersenet al, no qual a idosa deveria apresentar queixas de memória, sem repercussões nas atividades básicas e instrumentais de vida diária.A força muscular foi avaliada pela força de preensão palmar (FPP) utilizando o dinamômetro (Jamar $®)$ e a força extensora do joelho (FEJ) pelo movimento de 1 repetição máxima (1-RM). O desempenho funcional de membros inferiores (MMII) foi avaliado pelo instrumento Short Physical Performance Battery (SPPB) e a composição corporal pela ImpedânciaBioelétrica (Biodynamics Model 310). Resultados: Foi encontrada diferença significativa na força muscular entre os grupos, sendo que o grupo de idosas com CCL apresentou menor FPP $(p=0,002)$ e menor FEJ $(p=0,002)$. As demais variáveis como SPPB e a composição corporal não apresentaram diferença significativa entre os grupos. Quanto às correlações, obteve-se correlação positiva significativa entre o SPPB e a FEJ ( $r=0,55 ; p=0,0001)$, o $S P P B$ e a FPP $(r=0,37 ; p=0,0155)$, a FEJ e a FPP $(r=0,59 ; p<0,0001)$, e entre a massa magra e a FPP $(r=0,36$; $p=0,0184)$. Conclusão: A força muscular dos MMII e a FPP estão diminuídas nas idosas com CCL, diferentemente do desempenho funcional de MMII e da composição corporal que não foram diferentes entre os grupos.

Palavras-chave: Força Muscular. Composição Corporal. Comprometimento Cognitivo Leve. Idosos.

\section{Introduction}

Cognitive alterations, such as the forgetting of recent events, difficulties in performing calculations or an attention deficit, may be observed in aging and are often considered 'natural' and inherent to aging (1). More significant cognitive impairment leads to functional impairment, including mental functioning such as storing information, reasoning, remembering, and responding to external stimuli (2).

Mild Cognitive Impairment (MCI) refers to cognitive decline that is greater than that expected for an individual's age and educational level. MCI is more predominant in females than males, usually occurs in people aged 60 years or older, and often evolves to dementia conditions and diseases, especially to Alzheimer's disease. Prevalence is estimated at 3.2\% in people aged 60 years; $6 \%$ in people aged 65-79; and $15 \%$ in people aged 75-95 (3-7).

There are reports in the literature that individuals with MCI may exhibit some or no impairment in the performance of daily life activities such as climbing stairs or manipulating objects $(8,9)$. Some studies have shown that cognitive impairment, such as memory alteration and executive dysfunction, may be even more detrimental to an individual's functional capacity $(8-11)$. Notwithstanding, it remains unclear which functional losses occur in this population or whether these people exhibit differences in muscle 
strength or body composition, which are variables that may affect their functional capacity.

Given the above, this study aimed to assess muscle strength, lower extremity functional performance and body composition in elderly women with MCI.

\section{Methods}

This was an observational study with cross-sectional design. The methodological design used a convenience sample selected in Brasília, DF, Brazil, and surrounding municipalities, from the Unidade Mista de Saúde of Taguatinga, DF (UMST), a referral outpatient clinic for geriatrics and gerontology of the State Department of Health of the Federal District, and the Centro de Convivência do Idoso of the Catholic University of Brasília (CCI-UCB).

This study was approved by the Research Ethics Committee of the Foundation for Education and Research in Health Sciences of the Department of Health of the Federal District - FEPECS/SES-DF (Protocol 614.767). All participants were informed about the nature of the study and gave written informed consent to participate.

The study included women aged $60-80$ years who were physically capable of performing the tests. Participants were divided into two different groups: a group with $\mathrm{MCI}$ and a group without MCI.

The exclusion criteria were presenting with: mobility dependency (not being able to walk at least 10 meters); amaurosis; vestibulopathies; neurological diseases (such as stroke sequelae and Parkinson's disease) that could impede the performance of physical tests; history of lower limb fracture in the previous six months; painful symptoms or edema in the lower limbs; incapacitating orthopedic or rheumatologic diseases; orthoses or prostheses; serious cardiorespiratory diseases that would impede the performance of the tests.

MCI was assessed by a geriatric physician, using the criteria proposed by Petersen et al. (12): 1memory complaint by the informant (older woman), corroborated by a family member and/or caregiver; 2- objective memory impairment as assessed by the following tests: Mini-Mental State Examination (MMSE); word list memory test; picture memory test; verbal fluency test; clock drawing test (test scores must be below a cutoff value established according to educational level); 3- intact social and occupational function as assessed by the scales developed by Katz and Lawton\& Brody; 4- absence of dementia.

Forty-three elderly women met the inclusion and exclusion criteria and agreed to participate in the study. They were divided into two groups: a group of 19 elderly women with MCI and a group of 24 elderly women without MCI. Next, we scheduled the functional performance tests.

Participants were assessed on a single day. Assessments lasted approximately one hour and thirty minutes and were performed at the laboratory of Physical Assessment and Training LAFIT) and at the Laboratory of Studies on Physical Education and Health (LEEFS), located at the Taguatinga campus of the Catholic University of Brasília (UCB).

All the participants were assessed in the afternoon in a climatized room. To ensure result quality, they had been asked not to exercise the day before the test. Upon arrival, they were requested to complete a clinical questionnaire. Then they were subjected to the tests listed below.

Palmar Grip Strength (PGS) was assessed using a hydraulic hand-held dynamometer Jamar $^{\circledR}$ model 5030J1) with a scale readout reading kilograms of force $(\mathrm{kg} / \mathrm{f})$. The procedure was performed according to the recommendations of the American Society of Hand Therapists (ASHT) (13). The dominant side was measured thrice, and the mean of the three measures was recorded. Subjects were allowed a one minute rest time between measurements.

Knee extension strength (KES) was assessed using the one-repetition maximum test (1-RM) on a leg extension machine (14). Participants performed 6-10 warm-up repetitions with approximately 50\% of the load that would be used on the first trial of each test session (15). The assessment was started two minutes after warm-up. Participants were instructed to perform two repetitions of the movement. If the subject was able to complete two repetitions on the first trial or if a subject was not able to complete any repetition of the test, after a 3- to 5 -minute recovery period the load was increased or decreased accordingly and a second trial was performed. In case the one-repetition maximum load was still not determined, the movement was repeated on a third trial. Thus, the 1-RM load was designated as the load with which the subject was able to complete one single repetition of the knee extension exercise (16-18). 
The Short Physical Performance Battery (SPPB) was administered to assess lower extremity physical performance $(19,20)$. The SPPB assesses balance (with the feet in three different positions: together, semi-tandem and tandem), gait speed (three or four meters) and LE strength (sitting down and getting up from a chair five times). Each test was timed with a stopwatch and given a score ranging from 0 to 12 that was summed for all tests. The resulting value represented the LE performance of participants: a score of 0-3 points implied that the subject was unable to perform any of the tests or showed a very bad performance; a score of 4-6 points indicated low performance; a score of 7-9 points meant moderate performance; and a score of $10-12$ points evidenced good performance.

We used bioelectrical impedance analysis (BiodynamicsModel 310 V6.0) to calculate body composition (BC). Proximal electrodes were attached to the ipsilateral wrist and ankle, and to the right dimidium, while distal electrodes where attached to the metacarpus and metatarsus. The tests were performed at least 1 hour after food intake (21). Before the examination, participants were asked to empty their bladder, remove all metallic objects and lie down on a stretcher, as relaxed and motionless as possible, with their arms $30^{\circ}$ away from their trunk and their legs $45^{\circ}$ apart from one another (22). Lean mass (LM) and fat mass (FM) were assessed in kilograms (kg), according to the information displayed on the device.

All data are presented as mean and standard deviation. For categorized variables, the results were expressed in absolute and relative values. The data were checked for normality, using KolmogorovSmirnov and Shapiro-Wilk tests. Student's t-test was used to compare means between two samplesand Pearson's correlation coefficient was used to assess the linear relationship between continuous variables. The following correlation strength 'categories' were adopted in this study: Positive, strong correlation between 0.8 and 1; positive, moderate correlation between 0.3 and 0.6 ; positive, weak correlation between 0.0 and 0.2 ; negative, strong correlation between -0.7 and -1 ; negative, moderate correlation between -0.3 and -0.6; and negative, weak correlation between - 0.0 and -0.3. The level of significance was set at $5 \%$. (23). Statistical analysis was performed using Statistical Analysis System (SAS) software.

\section{Results}

Participants were divided into two groups: elderly women without MCI $(n=24)$ and eldery women with MCI ( $\mathrm{n}=19)$.

The clinical characteristics of elderly women with and without MCI are shown as mean and standard deviation in Table 1.

Table 1 - Age, weight, height and BMI of the sample (mean \pm standard deviation)

\begin{tabular}{lccc}
\hline VARIABLES & $\begin{array}{c}\text { WITHOUT MCI } \\
\mathbf{N}=\mathbf{2 4}\end{array}$ & $\begin{array}{c}\text { WITH MCI } \\
\mathbf{N}=\mathbf{1 9}\end{array}$ & $\mathbf{P}$ \\
\hline Age (years) & $67.17 \pm 6.05$ & $70.47 \pm 6.43$ & 0.09 \\
Weight $(\mathrm{Kg})$ & $67.19 \pm 14.62$ & $62.89 \pm 13.03$ & 0.33 \\
Height $(\mathrm{m})$ & $1.549 \pm 0.07$ & $1.523 \pm 0.05$ & 0.18 \\
BMI $(\mathrm{kg} / \mathrm{m} 2)$ & $27.83 \pm 4.79$ & $27.15 \pm 5.66$ & 0.68 \\
\hline
\end{tabular}

Note: $\mathrm{MCl}=$ Mild Cognitive Impairment, BMI = Body Mass Index. $P$ - Student's t-test.

Normality of all variables (KES, PGS, SPPB, lean mass (LM), fat mass (FM), fat percentage and BMI) was confirmed.

A between-groups comparison revealed a statistically significant difference in KES ( $p=0.002)$ and PGS $(p=0.002)$. Elderly women with MCI had the worst performance (Table 2).

Table 2 - Strength, body composition and functionality in the sample (mean \pm standard deviation)

\begin{tabular}{lccc}
\hline VARIABLES & $\begin{array}{c}\text { WITHOUT MCI } \\
\mathbf{N}=\mathbf{2 4}\end{array}$ & $\begin{array}{c}\text { WITH MCI } \\
\mathbf{N}=\mathbf{1 9}\end{array}$ & $\mathbf{P}$ \\
\hline KES $(\mathrm{kg})$ & $45.71 \pm 18.33$ & $26.95 \pm 17.90$ & 0.002 \\
PGS $(\mathrm{kg} / \mathrm{f})$ & $25.67 \pm 6.55$ & $19.24 \pm 5.91$ & 0.002 \\
SPPB (0-12 points) & $8.17 \pm 2.01$ & $8.32 \pm 2.11$ & 0.816 \\
LM $(\mathrm{kg})$ & $41.23 \pm 8.12$ & $37.85 \pm 6.15$ & 0.141 \\
FM $(\mathrm{kg})$ & $25.78 \pm 7.42$ & $24.94 \pm 8.38$ & 0.734 \\
FAT\% & $38.06 \pm 3.75$ & $38.93 \pm 5.64$ & 0.549 \\
\hline
\end{tabular}

Note: $\mathrm{MCl}=$ Mild Cognitive Impairment; KES $=$ Knee Extension Strength; PGS = Palmar Grip Strength; LM = lean mass; FM = fat mass; SPPB $=$ Short Physical Performance Battery. $\mathrm{P}-$ Student's t-test.

The correlation results are shown in Table 3. We found a moderate, positive correlation between SPPB and KES ( $r=0.55, p=0.0001)$ and between KES and 
PGS $(r=0.59$ and $p=0.0001)$; and weak correlations between SPPB and PGS $(r=0.37$ and $p=0.0155)$ and between LM and PGS ( $r=0.36$ and $p=0.0184)$.

Table 3 - Correlation between strength, functionality, body composition in the sample $(\mathrm{N}=43)$

\begin{tabular}{lcc}
\hline Variables & $\mathbf{r}$ & $\mathbf{P}$ \\
\hline SPPB and KES & $\mathbf{0 . 5 5}$ & $\mathbf{0 . 0 0 0 1}$ \\
SPPB and LM & 0.20 & 0.1929 \\
SPPB and FM & 0.07 & 0.6438 \\
SPPB and PGS & $\mathbf{0 . 3 7}$ & $\mathbf{0 . 0 1 5 5}$ \\
LM and PGS & $\mathbf{0 . 3 6}$ & $\mathbf{0 . 0 1 8 4}$ \\
FM and PGS & 0.14 & 0.3579 \\
FM and KES & 0.04 & 0.8020 \\
KES and PGS & $\mathbf{0 . 5 9}$ & $\mathbf{0 . 0 0 0 1}$ \\
KES and BMI & 0.09 & 0.5506 \\
PGS and BMI & 0.12 & 0.4428 \\
\hline
\end{tabular}

Note: KES = Knee Extension Strength; PGS = Palmar Grip Strength; LM $=$ Lean Mass, FM = Fat Mass; SPPB = Short Physical Performance Battery; BMI = Body Mass Index. P - Pearson's correlation.

\section{Discussion}

The results of this study show a significant difference in KES and PGS between the two groups, and that the group with MCI had the worst performance. Our findings reveal that MCI is associated with impaired LE strength and PGS.

The results of these study do not show that MCI is detrimental to functionality, especially LE functionality, as assessed by the SPPB, because th,ere was no significant difference in scores between the group with and without MCI. In addition, according to the sum of the scores on each SPPB test, both groups showed moderate performance (7-9 points) (22).

There was a positive correlation between functionality and KES and PGS. These results corroborate the findings by Puthoff \& Nielsen (24), who showed a moderate correlation between muscle strength and functionality in community-resident older adults. Thus, it can be inferred that, the greater the exerted force, the better the performance in functional tasks.

Some studies state that loss of muscle strength is the main responsible for reduced functional capacity in older adults and may be directly related to cognitive function, regardless of pathologies, lack of physical exercise and muscle mass $(25,26)$. In this study, we found a moderate correlation between PGS and KES and LM, as assessed by bioelectrical impedance analysis. These findings are in line with the study by Garcia et al. (27), which presents significant data on the correlation between PGS and LE muscle function and suggests that PGS is a predictor for the monitoring of LE muscle function in community-resident older adults. Martin, Nebuloni \& Najas (28) also found a positive correlation between PGS and the other body muscles and the assessment was considered a good predictor of physical performance in older adults.

Participants' low performance in the PGS test and in the walk test are strongly associated with MCI. Boyle et al. (29) state that impaired motor functions as assessed by the PGS and the walk test serve to determine prognostic implications and cognitive deficits in older adults. Wang et al. (30) also found similar results and showed that gait speed and reduced physical function are early warning signs of dementia, especially in older adults with MCI. Additionally, the authors conclude that poor PGS is associated with a greater decline in cognition.

We found no significant difference in BMI between groups, which suggests that MCI does not affect weight loss or gain and that there is no correlation between BMI and KES and PGS.

One limitation of this study was the small sample size, especially for the group with MCI. Moreover, this study has limitations that are inherent to cross-sectional studies, as it does not show cause-and-effect relationships between muscle strength and cognitive impairment but rather represents a moment in the lives of a group of people, without identifying factors that led to the existing situation. The sample of this study consisted of elderly women living in the community and our results therefore cannot be universally applied to all elderly adults.

Further longitudinal studies with larger samples are needed, as well as studies assessing the impact of MCI on quality of life and society.

Despite the aforementioned limitations, the findings of this study evidenced that elderly women with MCI have reduced LE muscle strength and palmar grip strength.

The tests used in this study are easy to handle and have good applicability in determining the functional impact of MCI. In the area of physical therapy, it is important to investigate muscle strength in older adults with MCI because it is known that Alzheimer's disease leads to reduced muscle strength, but muscle 
strength loss had not yet been documented in elderly women with MCI. Thus, in addition to compromising the lives of elderly women due to the impairment of cognitive functions, $\mathrm{MCI}$ is also detrimental to muscle strength and may generate risks of functional impairments and falls in this population.

\section{Conclusion}

The findings of this study show that LE muscle strength and palmar grip strength are reduced in elderly women with MCI. Moreover, this study reinforces the premise that elderly women with MCI do not show impaired functional capacity.

\section{References}

1. Braver TS, BArch DM. A theory of cognitive control, aging cognition, and neuromodulation. NeurosciBiobehav Rev. 2002;26(7):809-17.

2. Nascimento RAS, Batista RTS, Rocha SV, Vasconcelos LRC. Prevalência e fatores associados ao declínio cognitivo em idosos com baixa condição econômica: estudo MONIDI. J Bras Psiquiatr. 2015;64(3):187-92.

3. Brum PS, Forlenza OV, Yassuda MS. Cognitive training in older adults with mild cognitive impairment. Dement Neuropsychol. 2009;3(2):124-31.

4. Petersen RC, Doody R, Kurz A, Mohs RC, Morris JC, Rabins PV, et al. Current concepts in mild cognitive impairment. Arch Neurol. 2001;58(12):1985-92.

5. Ritchie K, Artero S, Touchon J. Classification criteria for mild cognitive impairment: a population-based validation study. Neurology. 2001;56(1):37-42.

6. Busse A, Bischkopf J, Riedel-Heller SG, Angermeyer MC. Mild cognitive impairment: prevalence and incidence according to different diagnostic criteria Results of the Leipzig Longitudinal Study of the Aged(LEILA75+).Br J Psychiatry. 2003;182(5):449-54.

7. Simon SS, Ribeiro MPO. Comprometimento cognitivo leve e reabilitação neuropsicológica: uma revisão bibliográfica. Psic Rev. 2011;20(1):93-122.
8. McGuire LC, Ford ES, Ajani UA. Cognitive Functioning as a Predictor of Functional Disability in Later Life. Am J Geriatr Psychiatry. 2006;14(1):36-42.

9. Lopez OL. Mild cognitive impairment. Continuum (Minneap Minn). 2013;19(2 Dementia):411-24.

10. Mcalister C, Schmitter-Edgecombe M, Lamb R. Examination of Variables That May Affect the Relationship Between Cognition and Functional Status in Individuals with Mild Cognitive Impairment: A Meta-Analysis. Arch ClinNeuropsychol. 2016;31(2):123-47.

11. Kameyama K, Tsutou A, Fujino H. The relationship between health-related quality of life and higher-level functional capacity in elderly women with mild cognitive impairment. J Phys TherSci. 2016;28(4):1312-7.

12. Petersen RC, Stevens JC, Ganguli M, Tangalos EG, Cummings Jl, DeKosky ST. Practice parameter: early detection of dementia: mild cognitive impairment (an evidence-based review). Report of the Quality Standards Subcommittee of the American Academy of Neurology. Neurology. 2001;56(9):1133-42.

13. Fess EE. Grip Strength. In: Casanova JS. Clinical Assessment Recommendations. Chicago: American Society of Hand Therapists; 1992. p. 41-5.

14. Kraemer WJ, Fry AC. Strength testing: development and evaluation of methodology. In: Maud P, Foster C. Physiological assessment of human fitness. Champaign (IL): HumanKinetics, 1995.

15. Simão R, Lemos A, Castro LEV, Chaves CPG,Polito MD. Força muscular máxima na extensão de perna uni e bilateral. Rev BrasFisiolExer. 2003;2(1):47-57.

16. Pereira RIM, Gomes SC. Testes de força e resistência muscular: confiabilidade e predição de uma repetição máxima - Revisão e novas evidências. RevBras Med Esporte. 2003;9(5):325-35.

17. Dias RMR, Cyrino ES, Salvador EP, Caldeira LFS, Nakamura FY, Papst RR, et al. Influência do processo de familiarização para avaliação da força muscular em testes de 1-RM. Rev Bras Med Esporte. 2005;11(1):34-8.

18. Shimano T, Kraemer WJ, Spiering BA, Volek J, Hatfield DL, Silvestre R, et al. Relationship between the number of repetitions and selected percentages of one repetition maximum in free weight exercises in trained and untrained men. J Strength Cond Res. 2006;20(4):819-23. 
19. Guralnik JM, Simonsick EM, Ferrucci L, Glynm RJ, Berkman LF, Blazer DG, et al. A short physical performance battery assessing lower extremity function: association with self-reported disability and prediction of mortality and nursing home admission. J Gerontol. 1994;49(2):85-94.

20. Nakano MM. Versão Brasileira da Short Physical Performance Battery - SPPB: Adaptação Cultural e Estudo da Confiabilidade [master's thesis]. Campinas: Universidade Estadual de Campinas; 2007.

21. Vilaça KHC, Ferriolli E, Lima NKC, Paula FJA, Moriguti JC. Effect of fluid and food intake on the body composition evaluation of elderly persons. J Nutr Health Aging. 2009;13(3):183-6.

22. Sardinha LB, Lohman TG, Teixeira PJ, Guedes DP, Going SB. Comparison of air displacement plethysmography with dual-energy X-ray absorptiometry and 3 field methods for estimating body composition in middleaged men. Am J Clin Nutr. 1998;68(4):786-93.

23. Whitehead AL, Julious AS, Cooper CL, Campbell MJ. Estimating the sample size for a pilot randomised trial to minimise the overall trial sample size for the external pilot and main trial for a continuous outcome variable. Stat Methods Med Res. 2016;25(3):1057-73.

24. Puthoff ML, Nielsen DH. Relationships Among Impairments in Lower-Extremity Strength and Power, Functional Limitations, and Disability in Older Adults. Phys Ther. 2007;87(10):1334-47.
25. Matsudo SM, Matsudo VKR, Barros Neto TL, Araújo TL. Evolução do perfil neuromotor e capacidade funcional de mulheres fisicamente ativas de acordo com a idade cronológica. Rev Bras Med Esporte. 2003;9(6):365-76.

26. Auyeung TW, Kwok T, Lee J, Leung PC, Leung J, Woo J. Functional Decline in Cognitive Impairment - The Relationship between Physical and Cognitive Function. Neuroepidemiology. 2008;31(3):167-73.

27. Garcia PA, Dias JMD, Dias RC, Santos P, Zampa CC. Estudo da relação entre função muscular, mobilidade funcional e nível de atividade física em idosos comunitários. RevBrasFisioter. 2011;15(1):15-22.

28. Martin FG, Nebuloni CC, Najas MS. Correlação entre estado nutricional e força de preensão palmar em idosos. Rev Bras GeriatrGerontol. 2012;15(3):493-504.

29. Boyle PA, Buchman AS, Wilson RS, Leurgans SE, Bennet DA. Physical Frailty Is Associated with Incident Mild Cognitive Impairment in Community-Based Older Persons. JAm Geriatr Soc. 2010;58(2):248-55.

30. Wang L, Larson EB, Bowen JD, Belle GV. PerformanceBased Physical Function and Future Dementia in Older People. Arch Intern Med, 2006;166(10):1115-20.

Received in 05/31/2016

Recebido em 31/05/2016

Approved in 03/20/2017

Aprovado em 20/03/2017 